OPEN ACCESS

Edited by:

Jean-Christophe Augustin, Ecole Nationale Vétérinaire d'Alfort,

France

Reviewed by:

Louis Coroller,

University of Western Brittany, France

Sergio I Martinez-Monteagudo,

South Dakota State University, USA

*Correspondence:

Michael Gänzle

mgaenzle@ualberta.ca

Specialty section

This article was submitted to

Food Microbiology,

a section of the journal

Frontiers in Microbiology

Received: 26 July 2016

Accepted: 20 October 2016

Published: 03 November 2016

Citation:

Li H and Gänzle M (2016) Some Like It Hot: Heat Resistance of Escherichia coli in Food. Front. Microbiol. 7:1763. doi: 10.3389/fmicb.2016.01763

\section{Some Like It Hot: Heat Resistance of Escherichia coli in Food}

\author{
Hui Li' and Michael Gänzle ${ }^{1,2 *}$ \\ ${ }^{1}$ Department of Agricultural, Food and Nutritional Science, University of Alberta, Edmonton, AB, Canada, ${ }^{2}$ College of \\ Bioengineering and Food Science, Hubei University of Technology, Hubei, China
}

Heat treatment and cooking are common interventions for reducing the numbers of vegetative cells and eliminating pathogenic microorganisms in food. Current cooking method requires the internal temperature of beef patties to reach $71^{\circ} \mathrm{C}$. However, some pathogenic Escherichia coli such as the beef isolate E. coli AW 1.7 are extremely heat resistant, questioning its inactivation by current heat interventions in beef processing. To optimize the conditions of heat treatment for effective decontaminations of pathogenic E. coli strains, sufficient estimations, and explanations are necessary on mechanisms of heat resistance of target strains. The heat resistance of $E$. coli depends on the variability of strains and properties of food formulations including salt and water activity. Heat induces alterations of $E$. coli cells including membrane, cytoplasm, ribosome and DNA, particularly on proteins including protein misfolding and aggregations. Resistant systems of $E$. coli act against these alterations, mainly through gene regulations of heat response including EvgA, heat shock proteins, $\sigma^{\mathrm{E}}$ and $\sigma^{\mathrm{S}}$, to re-fold of misfolded proteins, and achieve antagonism to heat stress. Heat resistance can also be increased by expression of key proteins of membrane and stabilization of membrane fluidity. In addition to the contributions of the outer membrane porin $\mathrm{NmpC}$ and overcome of osmotic stress from compatible solutes, the new identified genomic island locus of heat resistant performs a critical role to these highly heat resistant strains. This review aims to provide an overview of current knowledge on heat resistance of $E$. coli, to better understand its related mechanisms and explore more effective applications of heat interventions in food industry.

Keywords: Escherichia coli, heat resistance, VTEC, food processing, protein, locus of heat resistance

\section{INTRODUCTION}

Pasteurization and domestic cooking are common interventions for reducing the numbers of vegetative bacterial cells including pathogens in food. Heat kills vegetative bacterial cells by inactivation of cellular components, particularly membranes, proteins, and ribosomes (Tsuchido et al., 1985; Mackey et al., 1991; Mohácsi-Farkas et al., 1999; Lee and Kaletunc, 2002). Thermal food processing has an excellent record of establishing and maintaining food safety. However, consumer preferences for raw or minimally processed food, and the aim to minimize thermal degradation of nutrients are incentives to reduce the intensity of thermal processing. Moreover, fresh foods including meats and produce cannot be heated to temperature that are lethal to all pathogens, and bacterial pathogens are highly resistant to thermal processing in the dry state (Santillana Farakos et al., 2014; Syamaladevi et al., 2016). In addition, the heat resistance of pathogens is variable and 
heat resistant strains may withstand thermal processes that are lethal to the majority of strains of the same species ( $\mathrm{Ng}$ et al., 1969; Murphy et al., 1999; Dlusskaya et al., 2011).

Escherichia coli has been considered to be a relatively heat sensitive organism; however, strains of $E$. coli belong to the most heat resistant vegetative foodborne pathogens (Figure 1; Jay et al., 2005; Doyle and Beuchat, 2013). Heat resistant E. coli have $\mathrm{D}_{60}$ value of more than $6 \mathrm{~min}$ (Figure 1; Liu et al., 2015; Mercer et al., 2015), and their resistance matches or exceeds Salmonella Senftenberg 755 with $\mathrm{D}_{60}$ of 6.3 min (Ng et al., 1969; Baird-Parker et al., 1970) and Staphylococcus aureus with $\mathrm{D}_{60}$ of 4.8-6.5 min (Jay et al., 2005; Kennedy et al., 2005; Doyle and Beuchat, 2013). Foodborne disease with E. coli has been linked to consumption of meat and meat products as well as fruits and fresh produce (Frenzen et al., 2005; Karch et al., 2005; Greig and Ravel, 2009; Yeni et al., 2015). Heat treatments for effective microbial decontamination and minimum organoleptic deterioration of foods (Woodward et al., 2002; Klaiber et al., 2005; Rajic et al., 2007) necessitate knowledge of the heat resistance of target foodborne pathogens as well as factors influencing heat resistance. This review aims to provide an overview of current knowledge on mechanisms of heat resistance of $E$. coli to provide novel perspectives on conventional and novel thermal processing of foods. Major mechanisms of heat resistance are active in all strains of $E$. coli; however, relatively few studies elucidated genetic determinants for strain-specific acquisition of heat resistance. A recently identified genomic island termed locus of heat resistance (LHR) substantially increases the heat resistance of about 2\% of strains of E. coli (Mercer et al., 2015). Where appropriate, E. coli will be compared to Salmonella enterica, a closely related organisms exhibiting comparable resistance to heat.

\section{VARIABILITY OF RESISTANCE OF STRAINS OF E. coli TO HEAT}

The $\mathrm{D}_{60}$-value of E. coli $\mathrm{K} 12$ is reported as 0.1 to $0.3 \mathrm{~min}$ (Chung et al., 2007; Jin et al., 2008; Dlusskaya et al., 2011); however, a majority of strains of $E$. coli exhibits $\mathrm{D}_{60}$-values exceeding that value up to 10-fold (Figure 1). Heat resistance is not related to the phylogenetic group, the serotype, or the virotype of E. coli (Liu et al., 2015; Mercer et al., 2015). Highly heat resistant strains of $E$. coli exhibit $\mathrm{D}_{60}{ }^{\circ} \mathrm{C}$ values exceeding $10 \mathrm{~min}$ (Dlusskaya et al., 2011; Garcia-Hernandez et al., 2015). Genetic determinants of the variability of heat resistance between strains are only partially understood. An overview on isogenic mutant strains of E. coli and their heat resistance is shown in Table $\mathbf{1}$. Genes that are related to the heat shock response, including the alternative sigma factors $\sigma^{\mathrm{H}}$ and $\sigma^{\mathrm{E}}$, the heat shock proteins (HSPs) IbpA/B, the alternative sigma factor $\sigma^{S}$ regulating the general stress response, the oxidative stress response regulated by SodA/B, and genes related to envelope properties including synthase of colanic acid, cyclopropane fatty acids (CFAs), NmpC and EvgA relate to heat resistance (Table 1 and references therein). E. coli strains deficient of in $\sigma^{\mathrm{H}}, \sigma^{\mathrm{S}}$, SodA/B, IbpA/B, and colanic acid as well as CFAs were more sensitive to heat compared to their isogenic parental strains. Overexpression of EvgA increased heat

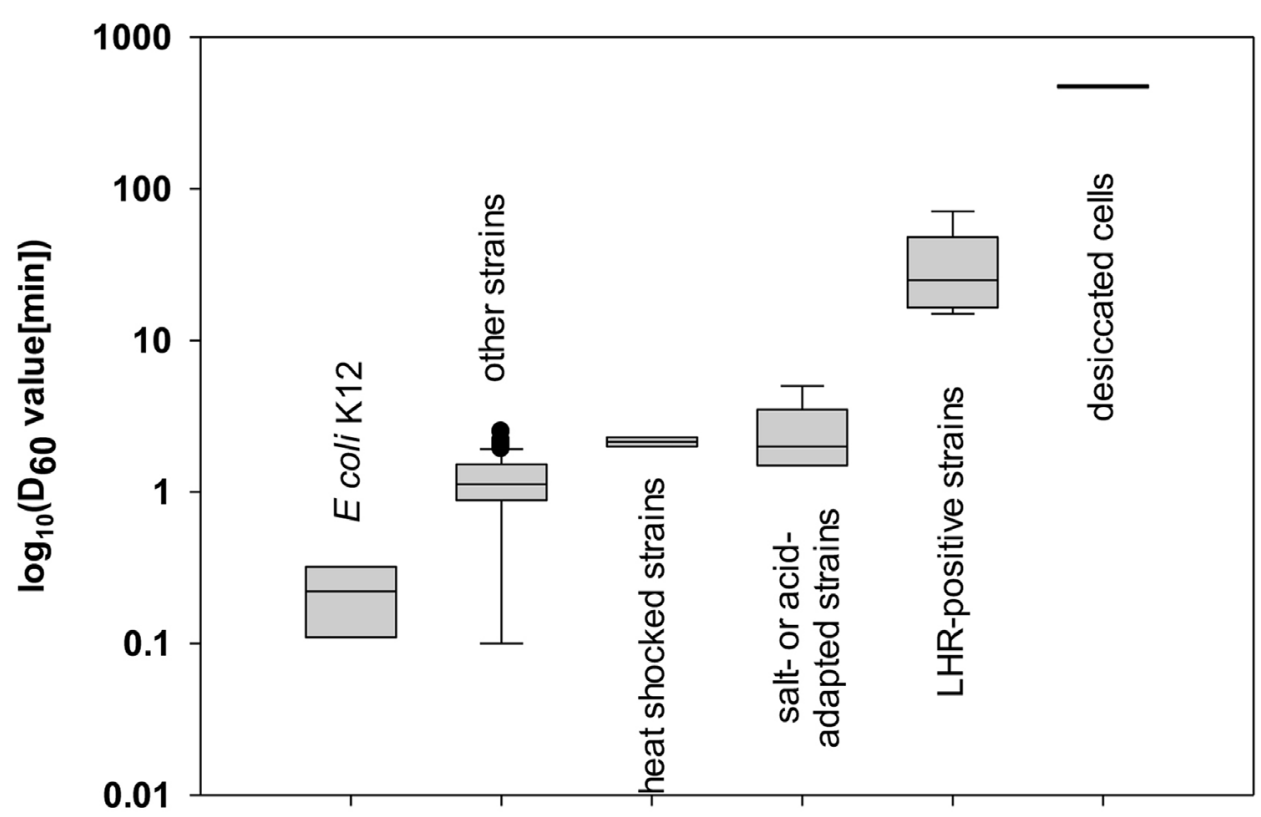

FIGURE 1 | Heat resistance of Escherichia coli. Data shown are $\log _{10}$ value of $D_{60}(\mathrm{~min})$ of 144 strains collected from past publications: three values of K-12 strains (Chung et al., 2007; Jin et al., 2008; Dlusskaya et al., 2011), 125 of other strains of E. coli (Juneja and Marmer, 1999; Dlusskaya et al., 2011; Enache et al., 2011; Pleitner et al., 2012; Liu, 2015; Mercer et al., 2015), 2 D-values of strains after overexpression of heat shock proteins (HSP) (Hauben et al., 1997; Ruan et al., 2011), 7 D-values of strains after adaptation to salt or acid stress (Buchanan and Edelson, 1999; Pleitner et al., 2012; Garcia-Hernandez et al., 2015), 5 D-values of LHR positive strains (Pleitner et al., 2012; Mercer et al., 2015), and 2 D-values of strains treated by dry heat (Neetoo and Chen, 2011; Kim et al., 2015). 
TABLE 1 | Effect of gene disruption or overexpression on heat resistance of $E$. coli.

\begin{tabular}{|c|c|c|c|c|}
\hline Escherichia coli serotype or strain number & Heat conditions (T/time) & Lethality $\left(\log N / N_{0}\right)$ & Medium /products & Reference \\
\hline $\begin{array}{l}\text { MC4100 (parental strain) } \\
\text { KY1601 }(\triangle r p o H)\end{array}$ & $57^{\circ} \mathrm{C}, 2 \mathrm{~min}$ & $\begin{array}{l}<0.1 \\
>3.5\end{array}$ & M9 medium & Jenkins et al., 1991 \\
\hline $\begin{array}{l}\text { AB1157 (parental strain) } \\
\text { Jl132 ( } \triangle \text { sodA sodB strain) }\end{array}$ & $48^{\circ} \mathrm{C}, 2 \mathrm{~h}$ & $\begin{array}{l}<0.5 \\
>6\end{array}$ & LB broth & Benov and Fridovich, 1995 \\
\hline $\begin{array}{l}\text { ATCC } 43895 \text { (parental strain) } \\
\text { FRIK } 816-3 \text { ( } \triangle \text { rpoS) }\end{array}$ & $55^{\circ} \mathrm{C}, 7 \mathrm{~min}$ & $\begin{array}{l}<1 \\
>4\end{array}$ & $\begin{array}{l}\text { Fermented } \\
\text { sausage }\end{array}$ & Cheville et al., 1996 \\
\hline $\begin{array}{l}\text { MC4100 } \\
\text { MC4100 ( } \triangle i b p A / B)\end{array}$ & $50^{\circ} \mathrm{C}, 4 \mathrm{~h}$ & $\begin{array}{l}<2 \\
>3\end{array}$ & LB broth & Kuczyñska-Wiśnik et al., 2002 \\
\hline $\begin{array}{l}\text { W6-13 (parental strain) } \\
\text { M4020 ( } \triangle \text { wca) }\end{array}$ & $60^{\circ} \mathrm{C}, 5 \mathrm{~min}$ & $\begin{array}{l}3.3 \\
6.6\end{array}$ & $\begin{array}{l}\text { Minimal } \\
\text { glucose broth }\end{array}$ & Mao et al., 2001 \\
\hline $\begin{array}{l}\text { AW1.7 } \\
\text { AW1.7 ( } \triangle c f a)\end{array}$ & $60^{\circ} \mathrm{C}, 30 \mathrm{~min}$ & $\begin{array}{l}2.0 \\
3.1\end{array}$ & LB broth & Chen and Gänzle, 2016 \\
\hline 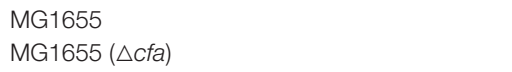 & $57^{\circ} \mathrm{C}, 15 \mathrm{~min}$ & $\begin{array}{l}1.3 \\
2.2\end{array}$ & LB broth & Chen and Gänzle, 2016 \\
\hline $\begin{array}{l}\text { BL21 } \\
\text { overexpression of lbpA/lbpB }\end{array}$ & $50^{\circ} \mathrm{C}, 30 \mathrm{~min}$ & $\begin{array}{l}1.5 \\
0.7-0.9\end{array}$ & M9 medium & Kitagawa et al., 2000 \\
\hline $\begin{array}{l}\text { E. coli W3110 } \\
\text { overexpression of EvgA }\end{array}$ & $50^{\circ} \mathrm{C}, 2 \mathrm{~h}$ & $\begin{array}{l}5 \\
1.5\end{array}$ & TY broth & Christ and Chin, 2008 \\
\hline $\begin{array}{l}\text { GGG10 } \\
\text { overexpression of } \mathrm{NmpC}\end{array}$ & $60^{\circ} \mathrm{C}, 1 \mathrm{~min}$ & $\begin{array}{l}3.5 \\
0.5\end{array}$ & LB broth & Ruan et al., 2011 \\
\hline $\begin{array}{l}\text { AW1.7 (pRK767) } \\
\text { AW1.7 } \triangle \mathrm{pHR} 1 \text { (pRK767) } \\
\text { AW1.7 } \triangle \mathrm{pHR} 1 \text { (pLHR) }\end{array}$ & $60^{\circ} \mathrm{C}, 5 \mathrm{~min}$ & $\begin{array}{l}<1 \\
>8 \\
<1\end{array}$ & LBbroth & Mercer et al., 2015 \\
\hline
\end{tabular}

LB, Luria-Bertani; TY, Tryptone-yeast extract.

resistance (Table 1). The LHR (Table 1) mediates extreme heat resistance with $\mathrm{D}_{60}$-values of 10 min or higher (Table 1). The heat resistance of strains of $E$. coli also depends on the food matrix (Table 2). The resistance of E. coli LTH5807 to heating on mung bean, radish, or alfalfa seeds differed substantially (Table 2). The survival of the LHR-positive E. coli AW1.7 in beef patties cooked to $71^{\circ} \mathrm{C}$ provides further evidence that the heat resistance of E. coli depends on the food matrix. Heat treatments that are considered to be lethal to $E$. coli thus may fail to safely eliminate contaminating E. coli (Table 2).

\section{MECHANISMS RELATED TO OUTER MEMBRANE AND MEMBRANE FLUIDITY}

Cell surface structures and appendages provide the first line of defense to environmental stress. An overview of heat stress responses related to cell membranes and the periplasm is provided in Figure 2. Most strains of E. coli secrete extracellular polysaccharides, including colanic acid, which forms a thick mucoid matrix on the cell surface (Whitfield and Valvano, 1993; Mao et al., 2001). A colanic acid-deficient mutant of E. coli M4020, obtained by insertional disruption of the wsc genes required for colanic acid biosynthesis, was less tolerant to exposure to 55 and $60^{\circ} \mathrm{C}$ than its parental strain E. coli O157:H7 W6-13 (Table 1), indicating that colanic acid confers heat resistance to E. coli O157:H7 (Figure 2) (Mao et al., 2001). Lipopolysaccharide (LPS) serves as a barrier to prevent rapid penetration of hydrophobic molecules, and is stabilized by divalent cations, particularly $\mathrm{Mg}^{2+}$ and $\mathrm{Ca}^{2+}$ (Figure 2) (Hitchener and Egan, 1977; Vaara, 1992; Hauben et al., 1998;
Li et al., 2016). Expression of the outer membrane porin $\mathrm{NmpC}$ increased survival of E. coli GGG10 at $60^{\circ} \mathrm{C}$ by 50- to 1,000-fold (Figure 2) (Ruan et al., 2011). The outer membrane permeabilizing polysaccharide chitosan decreased the heat resistance of $E$. coli in apple juice at $60^{\circ} \mathrm{C}$ (Liu, 2015). The pronounced effect on heat resistance of chitosan occurred on EHEC when combined with rutin or resveratrol in beef patties, due to the greater bacterial destruction from outer membrane to cytoplasmic membrane (Nair et al., 2016).

The fluidity of the membrane influences its function (Zhang and Rock, 2008). The adjustment of membrane lipid composition and membrane fluidity by homoviscous adaptation is a major contributor to the bacterial resistance to heat stress (Sinensky, 1974; Arneborg et al., 1993; Denich et al., 2003; Yuk and Marshall, 2003; Yoon et al., 2015). Adaptive systems responding to heat stress in E. coli contribute to the stabilization of membrane-bound enzymes, and affect physical properties of the cytoplasmic membrane (Torok et al., 1997; Beney and Gervais, 2001). Remarkably, heat resistance induced by slow heating of $E$. coli was related to adaptation of the membrane fluidity rather than protein synthesis (Guyot et al., 2010). Heatadaptation increased the heat resistance of $E$. coli strains by the maintenance of the membrane in the liquid-crystalline state. The incorporation of saturated fatty acids into membrane lipids reduces membrane fluidity (Nakayama et al., 1980; Katsui et al., 1981) and consequently antagonizes the heat-induced increase in fluidity (Figure 2) (Quinn, 1981; De Mendoza and Cronan, 1983; Suutari and Laakso, 1994; Mejía et al., 1995; Yuk and Marshall, 2003). The heat resistant E. coli AW1.7 was characterized by a higher proportion of saturated and CFAs in the cytoplasmic membrane when compared to heat sensitive strains of E. coli 
TABLE 2 | Examples of heat resistance of $E$. coli strains in food.

\begin{tabular}{|c|c|c|c|c|}
\hline Escherichia coli serotype or strain number & Heat conditions ( $T /$ time) & Lethality $\left(\log N_{0} / N\right)$ & Medium /products & Reference \\
\hline LTH5807 (O157:H' $\mathrm{H}^{-}$stx $\left.{ }^{-}\right)$ & $\begin{array}{l}60^{\circ} \mathrm{C}, 10 \mathrm{~min} \\
60^{\circ} \mathrm{C}, 3 \mathrm{~min} \\
60^{\circ} \mathrm{C}, 4 \mathrm{~min}\end{array}$ & $\begin{array}{l}>7.2 \\
>7.2 \\
5.9\end{array}$ & $\begin{array}{l}\text { Mung bean } \\
\text { Radish } \\
\text { Alfalfa }\end{array}$ & Weiss and Hammes, 2005 \\
\hline 204P (O157:H7) & $\begin{array}{l}50^{\circ} \mathrm{C}, 300 \mathrm{~min} \\
55^{\circ} \mathrm{C}, 30 \mathrm{~min}\end{array}$ & $\begin{array}{l}3-5 \\
2-4\end{array}$ & $\begin{array}{l}\text { Pork sausage } \\
\text { (7-30\% fat) }\end{array}$ & Ahmed et al., 1995 \\
\hline $\begin{array}{l}\text { AW1.7 } \\
\text { AW1.7 } \triangle \mathrm{pHR} 1 \\
\text { GGG10 }\end{array}$ & Internal $63 / 71^{\circ} \mathrm{C}$ & $\begin{array}{l}3-5^{\# / 3.5} \\
4-7^{\# / 5} \\
4.5 / \text { UDL }\end{array}$ & Beef patties & Liu et al., 2015 \\
\hline MG1655 (K12), LMM1030 & Internal $63^{\circ} \mathrm{C}$ & $5-6^{\#}$ & Beef patties & Liu et al., 2015 \\
\hline O26, O104, O111, O121, and 0157 & Internal $63^{\circ} \mathrm{C}$ & $2-\mathrm{NC}$ & Beef patties & Liu et al., 2015 \\
\hline O26, O104, and 0121 & Internal $71^{\circ} \mathrm{C}$ & $6-\mathrm{NC}$ & Beef patties & Liu et al., 2015 \\
\hline $\begin{array}{l}\text { O157:H7 (VTEC) } \\
\text { Non-O157 (VTEC) }\end{array}$ & Internal $49-71^{\circ} \mathrm{C}$ & $\begin{array}{l}3.2-4.1 \\
2.5-4.5\end{array}$ & Beef steaks & Luchansky et al., 2012 \\
\hline 8- strain VTEC cocktail** & $\begin{array}{l}191.5^{\circ} \mathrm{C}, \leq 1.25 \mathrm{~min} \\
1.5-2.5 \mathrm{~min}\end{array}$ & $\begin{array}{l}1.6-5.1 \\
\text { UDL }\end{array}$ & $\begin{array}{l}\text { Single cubed } \\
\text { Beef steaks }\end{array}$ & Swartz et al., 2015 \\
\hline \multirow[t]{2}{*}{ 8- strain VTEC cocktail** } & $\begin{array}{l}\leq 3.0 \mathrm{~min} \\
3.5 \mathrm{~min}\end{array}$ & $\begin{array}{l}0.8-5.3 \\
\text { UDL }\end{array}$ & $\begin{array}{l}\text { Double cubed } \\
\text { Beef steaks }\end{array}$ & Swartz et al., 2015 \\
\hline & Temperature & $D$ value $(\min )$ & & \\
\hline $\begin{array}{l}\text { O157:H7 E0139 } \\
\text { SEA 13B88 }\end{array}$ & $57^{\circ} \mathrm{C}$ & $\begin{array}{l}8.2 / 9.1 \\
6.2 / 7.9\end{array}$ & $\begin{array}{l}\text { Cantaloupe/wat- } \\
\text { ermelon juice }\end{array}$ & Sharma et al., 2005 \\
\hline $\begin{array}{l}\text { Heat resistant strains of } 7 \text { VTEC serotypes (O26, } \\
045,0103,0111,0121,0145 \text {, and } 0157)\end{array}$ & $\begin{array}{l}56^{\circ} \mathrm{C} \\
60^{\circ} \mathrm{C} \\
62^{\circ} \mathrm{C}\end{array}$ & $\begin{array}{l}2.1-4.5 \\
0.4-1.0 \\
0.2-0.5\end{array}$ & Apple juice & Enache et al., 2011 \\
\hline ATCC25922 & $55^{\circ} \mathrm{C}$ & 10.9 & Goat milk & Pereira et al., 2006 \\
\hline 380-94 (O157:H7) & $\begin{array}{l}58^{\circ} \mathrm{C} \\
60^{\circ} \mathrm{C} \\
62^{\circ} \mathrm{C}\end{array}$ & $\begin{array}{l}14.4 \\
6.1 \\
2.5\end{array}$ & $\begin{array}{l}\text { Postfermented } \\
\text { pepperoni }\end{array}$ & Riordan et al., 2000 \\
\hline $\begin{array}{l}\text { 4-strains cocktail of EDL-931, A 9218-C1, } \\
\text { 45753-35, } 933 \text { (all are O157:H7) }\end{array}$ & $\begin{array}{l}55^{\circ} \mathrm{C} \\
60^{\circ} \mathrm{C} \\
65^{\circ} \mathrm{C}\end{array}$ & $\begin{array}{l}11.5-12.0 \\
1.9-2.0 \\
0.3-0.4\end{array}$ & $\begin{array}{l}\text { Ground turkey, } \\
\text { lamb, and pork }\end{array}$ & Juneja and Marmer, 1999 \\
\hline
\end{tabular}

UDL, cell counts after treatment were under detection limit.

NC, no surviving cells after enrichment.

\#Reductions depend on fat content from 15 to 35\% in ground beef.

Thickness of beef steaks is 2.54 or $3.81 \mathrm{~cm}$; initial cell counts are around $5.50 \mathrm{cfu} / \mathrm{g}$.

**Temperature is the surface temperature; cooking time refers to the time per side; initial cell counts are around 6.3-6.8 cfu/g.

(Figure 2) (Ruan et al., 2011). A contribution of CFAs to heat resistance of $E$. coli was confirmed by disruption of $c f a$ coding for CFA synthase (Chen and Gänzle, 2016). The cfa deficient derivatives of E. coli AW1.7 and MG1655 did not produce CFAs; the unsaturated fatty acid C16:1 and C18:1 replaced CFAs in membrane lipids and the mutant strain was less resistant to heat when compared to the parent strains (Figure 2) (Chen and Gänzle, 2016).

\section{REGULATION OF HEAT RESPONSE BY EvgA, HSPs, AND $\sigma^{\mathrm{E}}$}

Cytoplasmic mechanisms of heat resistance relate to the effect of HSPs and compatible solutes on protein folding, and to oxidative stress (Figure 3). The regulation of the heat shock response of E. coli is governed by the two alternative sigma factors $\sigma^{\mathrm{H}}$ and $\sigma^{\mathrm{E}}$ (Figure 3A). The heat shock response is induced by temperatures around the growth/no-growth interface which aggravate protein misfolding but permit gene expression and protein synthesis
(Lindner et al., 2008; Winkler et al., 2010; Govers et al., 2014; Lee et al., 2016). $\sigma^{\mathrm{H}}$ and $\sigma^{\mathrm{E}}$ are encoded by $r p o H$ and $r p o E$, regulate transcription of heat-shock regulons coping with protein misfolding in the cytoplasm and the periplasm, respectively, and mediate cytoplasmic stress and envelope stress responses (Bukau, 1993). HSPs including chaperones and proteases function by holding partially unfolded proteins to prevent aggregation of heat-denatured proteins, and disaggregation of denatured proteins to allow refolding or proteolytic degradation (Parsell and Lindquist, 1993; Landini et al., 2014; Lee et al., 2016). The small HSPs IbpA and IbpB are holdases; DnaK, DnaJ, GrpE facilitate protein folding during translation, and guide aggregated proteins to the disaggregase $\mathrm{ClpB}$. ClpP and other heat-shock proteases degrade aggregated proteins. The expression of HSPs is induced by $\sigma^{\mathrm{H}}$ under sublethal heat stress and increases heat resistance of E. coli (Arsène et al., 2000). A $\sigma^{\mathrm{H}}$ deletion in E. coli eliminated synthesis of HSPs including DnaK, GroEL, and HtpG and the resulting strain was very sensitive to exposure to $57^{\circ} \mathrm{C}$ (Table 1). Starvation significantly enhanced the heat resistance of this strain (Jenkins et al., 1991). Small HSPs prevent protein aggregation by 
Normal

Colanic acid protects cell

$\mathrm{Ca}^{2+}$ and $\mathrm{Mg}^{2+}$ stabilize lipid $\mathrm{A}$.
Heat stressed

antimicrobials

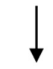

permeabilization

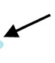

Colanic acid

extracellular

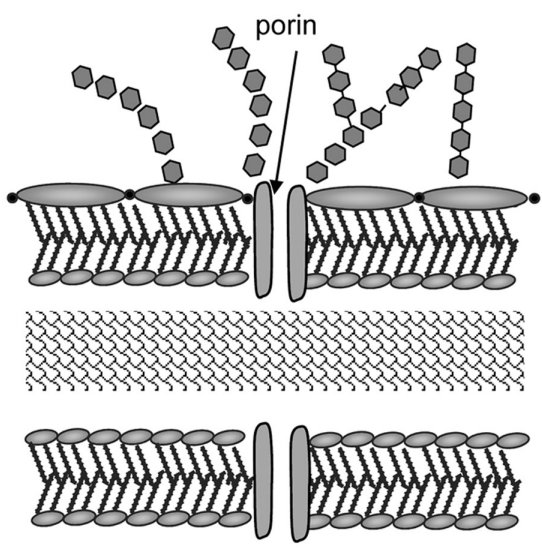

polysaccharides
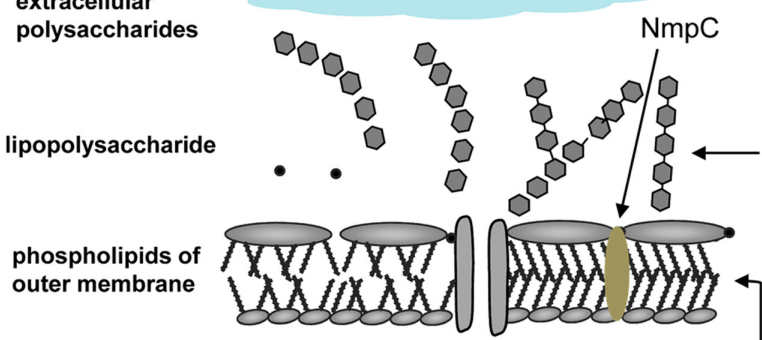

SurA and PpiD

peptidoglycan
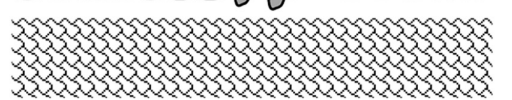

incorporation

of saturated

fatty acids

Cytoplasmic regulatory proteins with influence on envelope properties: evgA, $\sigma^{\mathrm{S}}$, and $\sigma^{\mathrm{E}}$

FIGURE 2 | Heat effects on cell membranes and attributes to heat resistance of $E$. coli. Extracellular polysaccharides including colanic acid forms a thick mucoid matrix on cell surfaces and provide protection of cells; disruption of wsc genes required for colanic acid biosynthesis substantially decreased heat resistance when compared to its parental strain (Whitfield and Valvano, 1993; Mao et al., 2001). LPS is a barrier to prevent rapid penetration of hydrophobic molecules, and is stabilized by divalent cations $\mathrm{Mg}^{2+}$ and $\mathrm{Ca}^{2+}$ against heat or pressure stress (Hitchener and Egan, 1977; Vaara, 1992; Hauben et al., 1998; Li et al., 2016). The solute transport proteins and the outer membrane porin NmpC contribute to heat resistance of E. coli AW1.7 (Ruan et al., 2011). Addition of antimicrobials including chitosan decreased the heat resistance due to the increased permeability of outer membrane (Liu, 2015). The master transcriptional regulator evgA is a cytoplasmic protein that increased heat resistance through activation of genes involved in periplasmic functions (Christ and Chin, 2008). The alternative sigma factors $\sigma^{\mathcal{S}}$ and $\sigma^{\mathrm{E}}$ also influence the properties of cell envelope (Lange and Hengge-Aronis, 1991; Bukau, 1993). LPS proteins SurA and PpiD lead to overall reduction in the level and folding of outer membrane proteins, consequently induce the periplamic heat shock response (Missiakas et al., 1996; Dartigalongue and Raina, 1998). Incorporating more saturated fatty acids such as palmitic acid and cyclopropane fatty acids (CFAs) into membrane lipids antagonizes the heat-induced increase in fluidity and achieves an ideal physical state of membrane (Katsui et al., 1981; Ruan et al., 2011; Chen and Gänzle, 2016). Disruption of cfa coding for CFA synthase of E. coli AW1.7 and MG1655 induced accumulation of the unsaturated fatty acid C16:1 and C18:1 in membrane lipids, consequently reducing the heat resistance of them (Chen and Gänzle, 2016).

heat (Jakob et al., 1993; Lee et al., 1997; Kitagawa et al., 2000; Mogk et al., 2003). Overexpression of IbpA and IbpB increased resistance not only to heat but also to superoxide (Kitagawa et al., 2000; Table 1). Small HSPs IbpA and IbpB prevent the aggregation of denatured endogenous proteins (Laskowska et al., 1996; Veinger et al., 1998; Kuczyñska-Wiśnik et al., 2002). The DnaK system also prevented protein aggregation induced by heat. This disaggregation is more efficient when DnaK acts in concert with ClpB (Mogk et al., 1999, 2003). However, disruption of $c l p A, h t p G$, and $i b p$ in E. coli did not affect the viability at $50^{\circ} \mathrm{C}$ (Thomas and Baneyx, 1998). The pressure resistant strains E. coli LMM1010, LMM1020, and LMM 1030 exhibit an increased basal expression of HSPs including DnaK, Lon, and ClpX; this increased expression may also account for the moderate increase of heat resistance of these strains (Hauben et al., 1997; Aertsen et al., 2004). Overall, the inducible heat shock response is a key contributor for growth of $E$. coli at temperature exceeding the optimum temperature of growth, but it makes only a modest contribution to the strain-specific differences of the resistance to lethal heat challenge.

Four key proteins involve in the regulation of $\sigma^{\mathrm{E}}$-dependent envelope stress response, including RseA, RseB, DegS, and Yael (Alba and Gross, 2004). The activity of $\sigma^{\mathrm{E}}$ is modulated by the expression of outer membrane proteins and outer membrane proteins induce $\sigma^{\mathrm{E}}$ activity (Mecsas et al., 1993). Moreover, deletions of LPS proteins SurA and PpiD lead to overall reduction in the level and folding of outer membrane proteins, and to the induction of the periplamic heat shock response (Figure 2) (Missiakas et al., 1996; Dartigalongue and Raina, 1998).

A master transcriptional regulator evgA activates genes involved in periplasmic functions, as well as in membrane and permeability functions. Its overexpression significantly increases heat resistance of E. coli (Christ and Chin, 2008; Table 1; Figure 2). The response regulator EvgA is part of a twocomponent regulatory system with sensor kinase EvgS, binding the intergenic region of evgAS and emrKY coding for efflux 


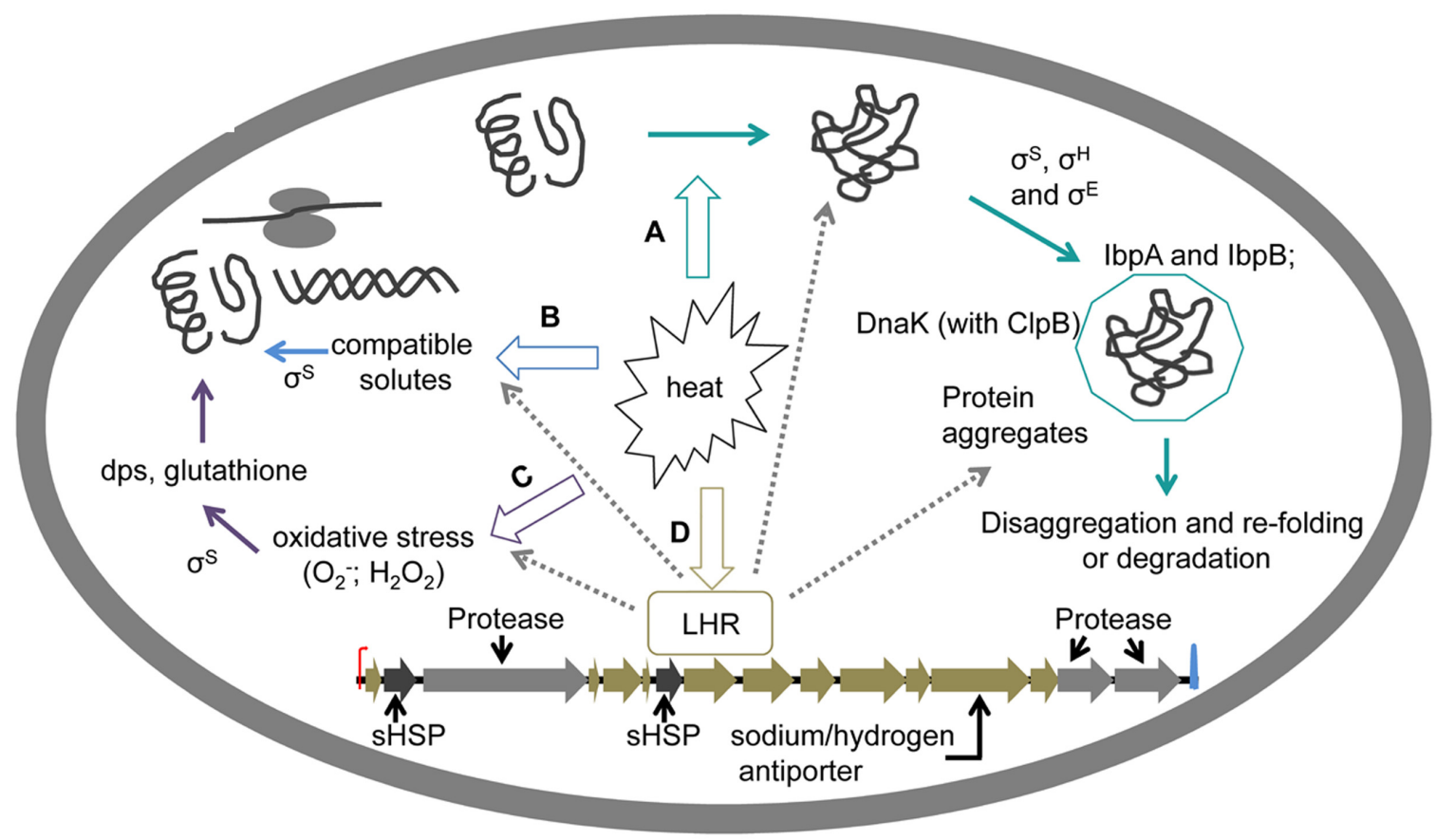

FIGURE 3 | Cytoplasmic determinants of heat resistance in E. coli. (A) Preventions of protein aggregation. Heat enhances misfolding of proteins and consequently induces protein aggregation. General stress response factors $\sigma^{\mathrm{S}}, \sigma^{\mathrm{H}}$, and $\sigma^{\mathrm{E}}$, as well as some small HSPs can suppress protein aggregation (Parsell and Lindquist, 1993; Landini et al., 2014).Small HSPs IbpA and IbpB bind to misfolded proteins and thus contribute to disaggregation of during sublethal heat shock (Laskowska et al., 1996; Veinger et al., 1998; Kuczyñska-Wiśnik et al., 2002). The DnaK system acts together with ClpB to prevent protein aggregation induced by heat (Mogk et al., 1999, 2003). (B) Compatible solutes accumulation induced by salt contributes to heat resistance through overcoming osmotic stress and stabilizing ribosomes (Ramos et al., 1997; Lamosa et al., 2000; Pleitner et al., 2012). Accumulation of amino acids including glycine betaine and proline as major cytoplasmic solutes, and the accumulation of carbohydrates including glucose and trehalose occurred in response to the addition of $\mathrm{NaCl}$ in $E$. coli, resulting in increased thermal stability of ribosomes during heat treatment (Pleitner et al., 2012). Mannosylglycerate and diglyerol phosphate protect proteins during heat treatment (Ramos et al., 1997; Lamosa et al., 2000). (C) Mitigation of oxidative stress. Oxidative stress induced by heat damages intracellular components including proteins, ribosomes and DNA. The general stress response factor $\sigma^{S}$ and the DNA binding protein dps acts against oxidative stress (Choi et al., 2000; Zhao et al., 2002; Landini et al., 2014). Pyruvate and catalase contribute to recovery of sublethally injured cells after heat treatments (Czechowicz et al., 1996; Mizunoe et al., 2000). (D) Regulation of the locus of heat resistance (LHR). LHR is unique genomic island contributing to extreme heat resistance in E. coli (Mercer et al., 2015). LHR contains 16 predicted ORF encoding small HSPs (sHSP, Orf2, and Orf7), hypothetical proteins yfdX family (Orf8 and Orf9), proteases (Orf3, Orf15, and Orf16), thioredoxin (Orf12), and sodium/hydrogen antiporters (Orf13), accordingly contributing to heat shock response, osmotic stress response, turnover of misfolded or disaggregation proteins, oxidative stress response, osmotic and heat stress response, respectively (Mercer et al., 2015; Lee et al., 2016). Predicted functions of LHR are indicated by dashed lines.

pump, and regulating the expression of both operons (Kato et al., 2000). Comparison of the genome-wide transcription profile of EvgA-overexpressing and EvgA-lacking strains revealed that EvgA conferred acid resistance to E. coli (Masuda and Church, 2002). EvgA controls the expression of wide range of genes, including $g a d A B C$, hdeAB, emrKY, yhiUV, and $y f d X$ which are related to acid resistance, osmotic adaptation, drug resistance and other functions (Nishino et al., 2003).

\section{REGULATION OF HEAT RESISTANCE BY $\sigma^{S}$, AND CROSS-RESISTANCE TO ACID, OXIDATIVE, AND HIGH PRESSURE STRESS}

Stationary phase cells are more resistant than exponential phase cells, mainly because of the increased expression of $\sigma^{\mathrm{S}}$ (Figure 3A) (Cheville et al., 1996; Kaur et al., 1998). The $\sigma^{S}$ regulon contributes to the general stress response and increase acid, heat, and / or osmotic resistance of E. coli (Hengge-Aronis et al., 1991; Cheville et al., 1996; Robey et al., 2001; HenggeAronis, 2002; Allen et al., 2008; Landini et al., 2014). Adaptation to acid stress provides cross-protection to heat stress (Ryu and Beuchat, 1998; Buchanan and Edelson, 1999; Ryu and Beuchat, 1999; Mazzotta, 2001; Yuk and Marshall, 2003). For example, adaptation of enterohemorrhagic E. coli to $\mathrm{pH} 4.6$ increased the heat resistance at $58^{\circ} \mathrm{C} 2-4$ fold when compared to cells grown at $\mathrm{pH} 7.0$ (Buchanan and Edelson, 1999). Induction of acid resistance in E. coli O157:H7 increases levels of CFAs in the cytoplasmic membrane (Brown et al., 1997), which stabilize cells against several environmental stressors including heat (Grogan and Cronan, 1997; Chen and Gänzle, 2016). Moreover, $\sigma^{S}$ dependent gene expression increased the heat resistance of $E$. coli O157:H7 after adaptation to temperatures above the optimum growth temperature (Cheville et al., 1996; Yuk and Marshall, 2003; Table 1). Starvation of E. coli O157:H7 substantially 
increased $\mathrm{D}_{52}$-values; this enhanced heat resistance was related to the expression of starvation-induced proteins UspA and GrpE (Zhang and Griffiths, 2003).

Heat induces production of $\mathrm{O}_{2}$ in $E$. coli under aerobic conditions, possibly by disruption of the electron transport systems of the membrane, and consequently induces the manganese-containing superoxide dismutase (Privalle and Fridovich, 1987). Accumulation of reactive oxygen species after exposure to sublethal stress results in lethal damage to DNA, RNA, proteins, and lipids (Aldsworth et al., 1999; Cabiscol et al., 2000; Aertsen et al., 2005). The general stress response factor $\sigma^{S}$ also protects against oxidative stress (Figure 3C) (Landini et al., 2014). The $\sigma^{\mathrm{S}}$-regulated DNA binding protein dps binds DNA as homo-dodecamer and prevents DNA damage by oxidative stress or low pH (Choi et al., 2000; Zhao et al., 2002). The synthesis of CFAs in E. coli also increases resistance to oxidative stress (Grogan and Cronan, 1997). Proteins that are alter the resistance of $E$. coli to pressure-induced oxidative stress, including systems for thiol-disulfide redox homeostasis and proteins containing iron-sulfur clusters, probably also contribute against oxidative stress induced by heat (Malone et al., 2006; Charoenwong et al., 2011; Imlay, 2013; Gänzle and Liu, 2015).

Oxidative stress induced by sublethal thermal damage may also account for the phenomenon termed "viable but nonculturable state" (VBNC). VBNC cells cannot be detected by standard culture techniques but can be resuscitated under favorable conditions (Bogosian et al., 2000; Gupte et al., 2003; Morishige et al., 2013). Addition of sodium pyruvate recovered cells of $E$ coli after heat-induced sublethal injury. This protective effect was related to the ability of pyruvate to degrade hydrogen peroxide (Czechowicz et al., 1996; Mizunoe et al., 2000). Addition of sodium pyruvate or catalase to medium agar also resuscitated VBNC Salmonella Enteritidis or Vibrio vulnificus cells, respectively, which had become sensitive to hydrogen peroxide (Bogosian et al., 2000; Morishige et al., 2013).

\section{EFFECTS OF SALT OR SUGAR ADDITION IN HIGH MOISTURE FOODS}

The water activity of food and particularly the salt content influence the heat resistance of E. coli. E. coli responds to an increase of the osmotic pressure by accumulation or synthesis of compatible solutes, small organic solutes that balance the osmotic pressure without interfering with cytoplasmic functions (Kempf and Bremmer, 1998). High cytoplasmic concentrations of compatible solutes increase heat resistance of $E$. coli and other bacterial cells by stabilizing ribosomes and proteins through a mechanisms referred to as "preferential hydration" (Figure 3B) (Ramos et al., 1997; Lamosa et al., 2000; Pleitner et al., 2012). A reduction in water activity from 0.995 to levels between 0.98 and 0.96 in salt or sucrose solutions significantly enhanced the heat resistance of E. coli (Kaur et al., 1998). The heat resistance of several strains of $E$. coli was also increased by addition of 2-6\% of $\mathrm{NaCl}$ (Garcia-Hernandez et al., 2015). Addition of $2 \% \mathrm{NaCl}$ resulted in the accumulation of amino acids including glycine betaine and proline as major cytoplasmic solutes; accumulation of carbohydrates including glucose and trehalose occurred in response to the addition of $6 \% \mathrm{NaCl}$ (Pleitner et al., 2012). The accumulation of solutes corresponded to an increased heat resistance of $E$. coli, and a higher thermal stability of ribosomes (Pleitner et al., 2012). The effect of $\mathrm{NaCl}$ addition on solute accumulation and heat resistance of $E$. coli is observed at concentrations that are typical for food systems. A critical concentration of $\mathrm{NaCl}$ in ground beef, about $2.7-4.7 \%$, substantially increased heat resistance of E. coli O157:H7 at $55-62.5^{\circ} \mathrm{C}$ (Juneja et al., 2015). In addition, pre-exposure to 5\% $\mathrm{NaCl}$ at room temperature for $24 \mathrm{~h}$ increased the heat resistance of E. coli $\mathrm{O} 157: \mathrm{H7}$ at $55^{\circ} \mathrm{C}$ (Bae and Lee, 2010).

The effect of the fat content on heat resistance of $E$. coli is controversial. An increased fat content in food products increased the heat resistance of $E$. coli in some studies (Line et al., 1991; Huang et al., 1992; Ahmed et al., 1995; Smith et al., 2001; Liu et al., 2015), while other studies reported decreased resistance, no effect, or strain-specific effects (Kotrola and Conner, 1997; Vasan et al., 2014; Liu et al., 2015). The potential direct effects of fat on heat resistance of $E$. coli are confounded by the strong effect of fat on heat transfer in solid foods. Reduced heat transfer increases the heating times to a certain target temperature and thus profoundly affects process lethality.

\section{LHR AND EXTREME RESISTANCE TO HEAT}

Extreme heat resistance of $E$. coli is conferred by the LHR (Figure 3D, Mercer et al., 2015). The LHR is a genomic island of about $14 \mathrm{kbp}$ which encodes for 16 genes; six of these genes are unique to heat resistant strains of E. coli (Mercer et al., 2015). Acquisition of the LHR increases survival after exposure to $60^{\circ} \mathrm{C}$ for $5 \mathrm{~min}$ by more than $7 \log (\mathrm{cfu} / \mathrm{mL})$; the LHR is thus one of the most powerful mediators of heat resistance in E. coli (Table 1; Mercer et al., 2015). Loss of the LHR also reduces the pressure resistance in E. coli AW1.7 (GarciaHernandez et al., 2015; Liu et al., 2015; Mercer et al., 2015). Remarkably, the presence of a truncated LHR in wild type strains of E. coli, or cloning of fragments of the LHR had little effect on heat resistance, indicating that the 16 genes act in concert to provide heat resistance in LHR-positive strains (Mercer et al., 2015). A genomic island with high similarity to the LHR, the Pseudomonas aeruginosa clone C-specific genomic island (PACGI-1) was characterized in Pseudomonas (Lee et al., 2015).

The 16 predicted open reading frames (ORF) within LHR encode small HSPs (Orf2 and Orf7), proteins of the YfdX family with unknown function (Orf8 and Orf9), heat shock proteases (Orf3, Orf15 and Orf16), thioredoxin (Orf12), and a sodium/hydrogen antiporter (Orf13) (Mercer et al., 2015). According to the predicted function of proteins encoded by the LHR, the genomic island may thus contribute to the turnover of misfolded or aggregated proteins, the osmotic stress response, and mitigate oxidative stress (Mercer et al., 2015). The contribution of genes encoded by the LHR to protein folding and protein turnover was confirmed in the homologous 
gene cluster PACGI-1 in P. aeruginosa (Lee et al., 2015). The small HSPs sHsp20c and ClpG $\mathrm{GI}$ contribute to thermotolerance in $P$. aeruginosa through their function as holdases and disaggregating chaperones (Lee et al., 2015, 2016). Cloning of the homologous LHR proteins in E. coli, however, had no influence on the heat resistance in E. coli (Mercer et al., 2015), demonstrating that the effect of LHR-encoded genes is species specific, and that extreme heat resistance in E. coli necessitates HSPs acting in concert with other biochemical functions.

\section{HEAT RESISTANCE OF DESICCATED E. coli}

Desiccated strains of E. coli and Salmonella are characterized by extreme resistance to physical and chemical stressors including heat (Beuchat and Scouten, 2002; Beuchat et al., 2013; Studer et al., 2013; Syamaladevi et al., 2016). Parameters for the heat inactivation of dry bacterial cells are comparable to the moist heat inactivation of bacterial endospores spores rather than pasteurization (Brandl et al., 2008; Du et al., 2010; Podolak et al., 2010). Hot air roasting of almonds even at very high temperature $\left(130-150{ }^{\circ} \mathrm{C}\right)$ achieve less than a $4 \mathrm{log}$ (cfu/g) reduction of Salmonella on almonds (Yang et al., 2010). Similarly a $2 \log (\mathrm{cfu} / \mathrm{g})$ reduction of Salmonella on dry alfalfa seeds required 10 days of treatment at $60^{\circ} \mathrm{C}$; an equivalent bactericidal effect was achieved after 5 min of treatment with wet heat at $60^{\circ} \mathrm{C}$ (Jaquette et al., 1996; Neetoo and Chen, 2011).

Mechanisms of dry heat resistance are best understood for Salmonella (Podolak et al., 2010; Finn et al., 2013). The heat resistance of Salmonella at $75^{\circ} \mathrm{C}$ in meat and bone meal was higher at aw 0.77 than at aw 0.88 (Riemann, 1968). Comparable to the effect of $\mathrm{NaCl}$ in high-moisture foods, the heat resistance of dry cells is related to the intracellular concentration of compatible solutes, including $\mathrm{K}^{+}$, glutamate and trehalose. The up-regulation of $\sigma^{S}, \sigma^{\mathrm{E}}$, fatty acid catabolism, and formations of $\mathrm{Fe}-\mathrm{S}$ clusters and filaments also contribute to the resistance to dry conditions (Finn et al., 2013). It was speculated that the extent and strength of the vibration of water molecules in dry bacteria are limited substantially because of the very low water contents. The low water content thus prevents denaturation of cytoplasmic and membrane proteins even at very high temperatures (Earnshaw et al., 1995; Archer et al., 1998). This mechanism was proposed in analogy to bacterial endospores, where the reduced core water reduces the amount of water associated with proteins, thus preventing thermal denaturation (Nicholson et al., 2000). Desiccation of bacterial

\section{REFERENCES}

Aertsen, A., De Spiegeleer, P., Vanoirbeek, K., Lavilla, M., and Michiels, C. W. (2005). Induction of oxidative stress by high hydrostatic pressure in Escherichia coli. Appl. Environ. Microbiol. 71, 2226-2231. doi: 10.1128/AEM.71.3.11551162.2005

Aertsen, A., Vanoirbeek, K., Spiegeleer, P. D., Sermon, J., Hauben, K., Farewell, A., et al. (2004). Heat shock protein-mediated resistance to high hydrostatic cells may also stabilize ribosomal units (Syamaladevi et al., 2016).

Several studies demonstrate that concepts and mechanisms that were identified in Salmonella are also relevant in E. coli. Desiccated VTEC survived at $70^{\circ} \mathrm{C}$ for $5 \mathrm{~h}$, thus exhibiting almost the same level of heat resistance as Salmonella (Hiramatsu et al., 2005). The lethality of treatments of radish seeds at $60^{\circ} \mathrm{C}$ against E. coli $\mathrm{O} 157: \mathrm{H} 7$ increased as the $\mathrm{a}_{\mathrm{W}}$ increased from 0.25 to 0.65 and 1.0 (Kim et al., 2015). However, information on the dry heat resistance of $E$. coli remains limited when compared to the information on the wet heat resistance of the organisms.

\section{CONCLUSION}

The resistance of $E$. coli strains to heat intervention treatments has been widely evaluated in the past decades, particularly using strains of E. coli O157: H7. Although E. coli has been considered as a relatively heat sensitive organisms, the $\mathrm{D}_{60}$ - values of some strains of E. coli are increased to several minutes or even hours by the heat shock response, adaptation to salt or acid stress, acquisition of the LHR, or desiccation (Figure 1). About $2 \%$ of E. coli including food isolates and pathogens harbor the LHR and exhibit extreme resistance to wet heat (Mercer et al., 2015). The biochemical function of the LHR links to proteins aggregation and folding as well as thiol- and ion homeostasis, however, the mechanisms of LHR -mediated heat resistance are only partially understood. Current pathogen intervention methods or cooking recommendations may not suffice to control these highly heat resistant strains of E. coli (Dlusskaya et al., 2011; Liu et al., 2015; Mercer et al., 2015). Additional hurdles need therefore to be developed to assure the inactivation of highly heat resistant strains. Further evaluations on inactivation of heat resistant strains under improved heat interventions and mechanisms of heat resistance allow us to design more effective applications in food industry.

\section{AUTHOR CONTRIBUTIONS}

All authors listed, have made substantial, direct and intellectual contribution to the work, and approved it for publication.

\section{ACKNOWLEDGMENTS}

HL is supported by China Scholarship Council. The Alberta Livestock and Meat Agency and Alberta Innovates Biosolutions are acknowledged for financial support.

pressure in Escherichia coli. Appl. Environ. Microbiol. 70, 2660-2666. doi: 10.1128/AEM.70.5.2660-2666.2004

Ahmed, N. M., Conner, D. E., and Huffman, D. L. (1995). Heat resistance of Escherichia coli $\mathrm{O} 157: \mathrm{H} 7$ in meat and poultry as affected by product composition. J. Food Sci. 60, 606-610. doi: 10.1111/j.1365-2621.1995.tb09838.x

Alba, B. M., and Gross, C. A. (2004). Regulation of the Escherichia coli sigma-dependent envelope stress response. Mol. Micribiol. 52, 613-619. doi: 10.1111/j.1365-2958.2003.03982.x 
Aldsworth, T. G., Sharman, R. L., and Dodd, C. E. (1999). Bacterial suicide through stress. Cell. Mol. Life Sci. 56, 378-383. doi: 10.1007/s000180050439

Allen, K. J., Lepp, D., McKellar, R. C., and Griffiths, M. W. (2008). Examination of stress and virulence gene expression in Escherichia coli O157:H7 using targeted microarray analysis. Foodborne Pathog. Dis. 5, 437-447. doi: 10.1089/fpd.2008.0100

Archer, J., Jervis, E. T., Bird, J., and Gaze, J. E. (1998). Heat resistance of Salmonella weltevreden in low-moisture environments. J. Food Prot. 61, 969-973.

Arneborg, N., Salskov-Iversen, A. S., and Mathiasen, T. E. (1993). The effect of growth rate and other growth conditions on the lipid composition of Escherichia coli. Appl. Microbiol. Biotechnol. 39, 353-357. doi: 10.1007/BF00192091

Arsène, F., Tomoyasu, T., and Bukau, B. (2000). The heat shock response of Escherichia coli. Int. J. Food Microbiol. 55, 3-9. doi: 10.1016/S01681605(00)00206-3

Bae, Y., and Lee, S. (2010). Effect of pre-exposure to sodium chloride on the resistance of pathogens to thermal and acid stresses. J. Food Saf. 30, 1016-1025. doi: 10.1111/j.1745-4565.2010.00259.x

Baird-Parker, A. C., Boothroyd, M., and Jones, E. (1970). The effect of water activity on the heat resistance of heat sensitive and heat resistant strains of Salmonellae. J. Appl. Microbiol. 33, 515-522.

Beney, L., and Gervais, P. (2001). Influence of the fluidity of the membrane on the response of microorganisms to environmental stresses. Appl. Microbiol. Biotechnol. 57, 34-42. doi: 10.1007/s002530100754

Benov, L., and Fridovich, I. (1995). Superoxide dismutase protects against aerobic heat shock in Escherichia coli. J. Bacteriol. 177, 3344-3346.

Beuchat, L. R., Komitopoulou, E., Beckers, H., Betts, R. P., Bourdichon, F., Fanning, S., et al. (2013). Low-water activity foods: increased concern as vehicles of foodborne pathogens. J. Food Prot. 76, 150-172. doi: 10.4315/0362-028X.JFP$12-211$

Beuchat, L. R., and Scouten, A. J. (2002). Combined effects of water activity, temperature and chemical treatments on the survival of Salmonella and Escherichia coli O157:H7 on alfalfa seeds. J. Appl. Microbiol. 92, 382-395. doi: 10.1046/j.1365-2672.2002.01532.x

Bogosian, G., Aardema, N. D., Bourneuf, E. V., Morris, P. J. L., and O'Neil, J. P. (2000). Recovery of hydrogen peroxide-sensitive culturable cells of Vibrio vulnificus gives the appearance of resuscitation from a viable but nonculturable state. J. Bacteriol. 182, 5070-5075. doi: 10.1128/JB.182.18.5070-5075.2000

Brandl, M. T., Pan, Z., Huynh, S., Zhu, Y., and McHugh, T. H. (2008). Reduction of Salmonella enteritidis population sizes on almond kernels with infrared heat. J. Food Prot. 71, 897-902.

Brown, J. L., Ross, T., McMeekin, T. A., and Nichols, P. D. (1997). Acid habituation of Escherichia coli and the potential role of cyclopropane fatty acids in low pH tolerance. Int. J. Food Microbiol. 37, 163-173. doi: 10.1016/S01681605(97)00068-8

Buchanan, R. L., and Edelson, S. G. (1999). Effect of pH-dependent, stationary phase acid resistance on the thermal tolerance of Escherichia coli O157:H7. Food Microbiol. 16, 447-458. doi: 10.1006/fmic. 1998.0260

Bukau, B. (1993). Regulation of the Escherichia coli heat-shock response. Mol. Microbiol. 9, 671-680. doi: 10.1111/j.1365-2958.1993.tb01727.x

Cabiscol, E., Tamarit, J., and Ros, J. (2000). Oxidative stress in bacteria and protein damage by reactive oxygen species. Int. Microbiol. 3, 3-8.

Charoenwong, D., Andrews, S., and Mackey, B. (2011). Role of rpoS in the development of cell envelope resilience and pressure resistance in stationary-phase Escherichia coli. Appl. Environ. Microbiol. 77, 5220-5229. doi: 10.1128/AEM.00648-11

Chen, Y. Y., and Gänzle, M. G. (2016). Influence of cyclopropane fatty acids on heat, high pressure, acid and oxidative resistance in Escherichia coli. Int. J. Food Microbiol. 222, 16-22. doi: 10.1016/j.ijfoodmicro.2016.01.017

Cheville, A. M., Arnold, W., Buchrieser, C., Cheng, M. M., and Kaspar, C. W. (1996). rpoS regulation of acid, heat, and salt tolerance in Escherichia coli O157:H7. Appl. Environ. Microbiol. 62, 1822-1824.

Choi, S. H., Baumler, D. J., and Kaspar, C. W. (2000). Contribution of dps to acid stress tolerance and oxidative stress tolerance in Escherichia coli O157:H7. Appl. Environ. Microbiol. 66, 3911-3916. doi: 10.1128/AEM.66.9.3911-3916.2000

Christ, D., and Chin, J. W. (2008). Engineering Escherichia coli heat-resistance by synthetic gene amplification. Protein Eng. Des. Sel. 21, 121-125. doi: 10.1093/protein/gzm085
Chung, H. J., Wang, S., and Tang, J. (2007). Influence of heat transfer with tube methods on measured thermal inactivation parameters for Escherichia coli. J. Food Prot. 70, 851-859.

Czechowicz, S. M., Santos, O., and Zottola, E. A. (1996). Recovery of thermallystressed Escherichia coli O157:H7 by media supplemented with pyruvate. Int. J. Food Microbiol. 33, 275-284. doi: 10.1016/0168-1605(96)01116-6

Dartigalongue, C., and Raina, S. (1998). A new heat-shock gene, ppiD, encodes a peptidyl-prolyl isomerase required for folding of outer membrane proteins in Escherichia coli. EMBO J. 17, 3968-3980. doi: 10.1093/emboj/17.14.3968

De Mendoza, D., and Cronan, J. E. Jr. (1983). Thermal regulation of membrane lipid fluidity in bacteria. Trends Biochem. Sci. 8, 49-52. doi: 10.1016/09680004(83)90388-2

Denich, T. J., Beaudette, L. A., Lee, H., and Trevors, J. T. (2003). Effect of selected environmental and physico-chemical factors on bacterial cytoplasmic membranes. J. Microbiol. Methods 52, 149-182. doi: 10.1016/S0167-7012(02)00155-0

Dlusskaya, E. A., McMullen, L. M., and Gänzle, M. G. (2011). Characterization of an extremely heat-resistant Escherichia coli obtained from a beef processing facility. J. Appl. Microbiol. 110, 840-849. doi: 10.1111/j.1365-2672.2011. 04943.x

Doyle, M. P., and Beuchat, L. R. (2013). Food Microbiology: Fundamentals and Frontiers. New York, NY: American Society for Microbiology Press.

Du, W., Abd, S. J., McCarthy, K. L., and Harris, L. J. (2010). Reduction of Salmonella on inoculated almonds exposed to hot oil. J. Food Prot. 73, 1238-1246.

Earnshaw, R. G., Appleyard, J., and Hurst, R. M. (1995). Understanding physical inactivation processes: combined preservation opportunities using heat, ultrasound and pressure. Int. J. Food Microbiol. 28, 197-219. doi: 10.1016/0168-1605(95)00057-7

Enache, E., Mathusa, E. C., Elliott, P. H., Black, D. G., Chen, Y., Scott, V. N., et al. (2011). Thermal resistance parameters for shiga toxin-producing Escherichia coli in apple juice. J. Food Prot. 74, 1231-1237. doi: 10.4315/0362-028X.JFP$10-488$

Finn, S., Condell, O., McClure, P., Amézquita, A., and Fanning, S. (2013). Mechanisms of survival, responses and sources of Salmonella in low-moisture environments. Front. Microbiol. 4:331. doi: 10.3389/fmicb.2013.00331

Frenzen, P. D., Drake, A., Angulo, F. J., and the Emerging Infections Program Foodnet Working Group (2005). Ecomomic cost of illness due to Escherichia coli O157 infections in the United States. J. Food Prot. 68, 2623-2630.

Gänzle, M. G., and Liu, Y. (2015). Mechanisms of pressure-mediated cell death and injury in Escherichia coli: from fundamentals to food applications. Front. Microbiol. 6:599. doi: 10.3389/fmicb.2015.00599

Garcia-Hernandez, R., McMullen, L., and Gänzle, M. G. (2015). Development and validation of a surrogate strain cocktail to evaluate bactericidal effects of pressure on verotoxigenic Escherichia coli. Int. J. Food Microbiol. 205, 16-22. doi: 10.1016/j.ijfoodmicro.2015.03.028

Govers, S. K., Dutre, P., and Aertsen, A. (2014). In vivo disassembly and reassembly of protein aggregates in Escherichia coli. J. Bacteriol. 196, 2325-2332. doi: 10.1128/JB.01549-14

Greig, J. D., and Ravel, A. (2009). Analysis of foodborne outbreak data reported internationally for source attribution. Int. J. Food Microbiol. 31, 77-87. doi: 10.1016/j.ijfoodmicro.2008.12.031

Grogan, D. W., and Cronan, J. E. Jr. (1997). Cyclopropane ring formation in membrane lipids of bacteria. Microbiol. Mol. Biol. Rev. 61, 429-441.

Gupte, A. R., De Rezende, C. L. E., and Joseph, S. W. (2003). Induction and resuscitation of viable but nonculturable Salmonella enterica serovar Typhimurium DT104. Appl. Environ. Microbiol. 69, 6669-6675. doi: 10.1128/AEM.69.11.6669-6675.2003

Guyot, S., Pottier, L., Ferret, E., Gal, L., and Gervais, P. (2010). Physiological responses of Escherichia coli exposed to different heat-stress kinetics. Arch. Microbiol. 192, 651-661. doi: 10.1007/s00203-010-0597-1

Hauben, K. J. A., Bartlett, D. H., Soontjens, C., Cornelis, K., Wuytack, E. Y., and Michiels, C. W. (1997). Escherichia coli mutants resistant to inactivation by high hydrostatic pressure. Appl. Environ. Microbiol. 63, 945-950.

Hauben, K. J. A., Bernaerts, K., and Michiels, C. W. (1998). Protective effect of calcium on inactivation of Escherichia coli by high hydrostatic pressure. J. Appl. Microbiol. 85, 678-684. doi: 10.1111/j.1365-2672.1998. 00577.x 
Hengge-Aronis, R. (2002). Signal transduction and regulatory mechanisms involved in control of the $\sigma \mathrm{S}$ (RpoS) subunit of RNA polymerase. Microbiol. Mol. Biol. Rev. 66, 373-395. doi: 10.1128/MMBR.66.3.373-395.2002

Hengge-Aronis, R., Klein, W., Lange, R., Rimmele, M., and Boos, W. (1991). Trehalose synthesis genes are controlled by the putative sigma factor encoded by rpoS and are involved in stationary-phase thermotolerance in Escherichia coli. J. Bacteriol. 173, 7918-7924.

Hiramatsu, R., Matsumoto, M., Sakae, K., and Miyazaki, Y. (2005). Ability of shiga toxin-producing Escherichia coli and Salmonella spp. to survive in a desiccation model system and in dry foods. Appl. Environ. Microbiol. 71, 6657-6663. doi: 10.1128/AEM.71.11.6657-6663.2005

Hitchener, B. J., and Egan, A. F. (1977). Outer-membrane damage in sublethally heated Escherichia coli K-12. Can. J. Microbiol. 23, 311-318. doi: 10.1139/ $\mathrm{m} 77-046$

Huang, I. D., Yousef, A. E., Marth, E. H., and Mathew, M. E. (1992). Thermal inactivation of Listeria monocytogenes in chicken gravy. J. Food Prot. 55, 492-496.

Imlay, J. A. (2013). The molecular mechanisms and physiological consequences of oxidative stress: lessons from a model bacterium. Nat. Rev. Microbiol. 11, 443-454. doi: 10.1038/nrmicro3032

Jakob, U., Gaestel, M., Engel, K., and Buchner, J. (1993). Small heat shock proteins are molecular chaperones. J. Biol. Chem. 268, 1517-1520.

Jaquette, C. B., Beuchat, L. R., and Mahon, B. E. (1996). Efficacy of chlorine and heat treatment in killing Salmonella stanley inoculated onto alfalfa seeds and growth and survival of the pathogen during sprouting and storage. Appl. Environ. Microbiol. 62, 2212-2215.

Jay, J. M., Loessner, M. J., and Golden, D. A. (2005). Modern Food Microbiology. New York, NY: Springer Science and Business Media Press.

Jenkins, D. E., Auger, E. A., and Matin, A. (1991). Role of RpoH, a heat shock regulator protein, in Escherichia coli carbon starvation protein synthesis and survival. J. Bacteriol. 173, 1992-1996.

Jin, T., Zhang, H., Boyd, G., and Tang, J. (2008). Thermal resistance of Salmonella enteritidis and Escherichia coli K-12 in liquid egg determined by thermaldeath-time disks. J. Food Eng. 84, 608-614. doi: 10.1016/j.jfoodeng.2007. 06.026

Juneja, V. K., Cadavez, V., Gonzales-Barron, U., and Mukhopadhyay, S. (2015). Modelling the effect of $\mathrm{pH}$, sodium chloride and sodium pyrophosphate on the thermal resistance of Escherichia coli O157:H7 in ground beef. Food Res. Int. 69, 289-304. doi: 10.1016/j.foodres.2014.11.050

Juneja, V. K., and Marmer, B. S. (1999). Lethality of heat to Escherichia coli O157:H7: D- and z-value determinations in turkey, lamb, and pork. Food Res. Int. 32, 23-28. doi: 10.1016/S0963-9969(99)00060-5

Karch, H., Tarr, P. I., and Bielaszewska, M. (2005). Enterohaemorrhagic Escherichia coli in human medicine. Int. J. Med. Microbiol. 295, 405-418. doi: 10.1016/j.ijmm.2005.06.009

Kato, A., Ohnishi, H., Yamamoto, K., Furuta, E., Tanabe, H., and Utsumi, R. (2000). Transcription of emrKY is regulated by the EvgA-EvgS two-component system in Escherichia coli K-12. Biosci. Biotechnol. Biochem. 64, 1203-1209. doi: 10.1271/bbb.64.1203

Katsui, N., Tsuchido, T., Takano, M., and Shibasaki, I. (1981). Effect of preincubation temperature on the heat resistance of Escherichia coli having different fatty acid compositions. J. Gen. Microbiol. 122, 357-361.

Kaur, J., Ledward, D. A., Park, R. W. A., and Robson, R. L. (1998). Factors affecting the heat resistance of Escherichia coli O157:H7. Lett. Appl. Microbiol. 26, 325-330. doi: 10.1046/j.1472-765X.1998.00339.x

Kempf, B., and Bremmer, E. (1998). Uptake and synthesis of compatible solutes as microbial stress responses to high-osmolality environments. Arch. Microbiol. 170, 319-330. doi: 10.1007/s002030050649

Kennedy, J., Blair, I. S., McDowell, D. A., and Bolton, D. J. (2005). An investigation of the thermal inactivation of Staphylococcus aureus and the potential for increased thermotolerance as a result of chilled storage. J. Appl. Microbiol. 99, 1229-1235. doi: 10.1111/j.1365-2672.2005.02697.x

Kim, Y. B., Kim, H. W., Song, M. K., and Rhee, M. S. (2015). Decontamination method using heat and relative humidity for radish seeds achieves a 7-log reduction of Escherichia coli O157:H7 without affecting product quality. Int. J. Food Microbiol. 201, 42-46. doi: 10.1016/j.ijfoodmicro.2015.02.015

Kitagawa, M., Matsumura, Y., and Tsuchido, T. (2000). Small heat shock proteins, IbpA and IbpB, are involved in resistances to heat and superoxide stresses in Escherichia coli. FEMS Microbiol. Lett. 184, 165-171. doi: 10.1111/j.15746968.2000.tb09009.x

Klaiber, R. G., Baur, S., Wolf, G., Hammes, W. P., and Carle, R. (2005). Quality of minimally processed carrots as affected by warm water washing and chlorination. Innov. Food Sci. Emerg. Technol. 6, 351-362. doi: 10.1016/j.ifset.2005.03.002

Kotrola, J., and Conner, D. E. (1997). Heat inactivation of Escherichia coli O157:H7 in turkey meat as affected by sodium chloride, sodium lactate, polyphosphate, and fat content. J. Food Prot. 60, 898-902.

Kuczyñska-Wiśnik, D., Kêdzierska, S., Matuszewska, E., Lund, P., Taylor, A., Lipiñska, B., et al. (2002). The Escherichia coli small heat-shock proteins IbpA and IbpB prevent the aggregation of endogenous proteins denatured in vivo during extreme heat shock. Microbiology 148, 1757-1765. doi: 10.1099/00221287-148-6-1757

Lamosa, P., Burke, A., Peist, R., Huber, R., Liu, M. Y., Silva, G., et al. (2000). Thermostabilization of proteins by diglycerol phosphate: a new compatible solute from the hyperthermophile Archaeoglobus fulgidus. Appl. Environ. Microbiol. 66, 1974-1979. doi: 10.1128/AEM.66.5.1974-1979.2000

Landini, P., Egli, T., Wolf, J., and Lacour, S. (2014). SigmaS, a major player in the response to environmental stresses in Escherichia coli: role, regulation and mechanisms of promoter recognition. Environ. Microbiol. Rep. 6, 1-13. doi: $10.1111 / 1758-2229.12112$

Lange, R., and Hengge-Aronis, R. (1991). Identification of a central regulator of stationary-phase gene expression in Escherichia coli. Mol. Microbiol. 5, 49-59. doi: 10.1111/j.1365-2958.1991.tb01825.x

Laskowska, E., Wawrzynów, A., and Taylor, A. (1996). IbpA and IbpB, the new heat-shock proteins, bind to endogenous Escherichia coli proteins aggregated intracellularly by heat shock. Biochimie 78, 117-122. doi: 10.1016/03009084(96)82643-5

Lee, C., Wigren, E., Lünsdorf, H., and Römling, U. (2016). Protein homeostasismore than resisting a hot bath. Curr. Opin. Microbiol. 30, 147-154. doi: 10.1016/j.mib.2016.02.006

Lee, C., Wigren, E., Trcek, J., Peters, V., Kim, J., Hasni, M. S., et al. (2015). A novel protein quality control mechanism contributes to heat shock resistance of worldwide-distributed Pseudomonas aeruginosa clone C strains. Environ. Microbiol. 17, 4511-4526. doi: 10.1111/1462-2920.12915

Lee, G. J., Roseman, A. M., Saibil, H. R., and Vierling, E. (1997). A small heat shock protein stably binds heat-denatured model substrates and can maintain a substrate in a folding-competent state. EMBO J. 16, 659-671. doi: 10.1093/emboj/16.3.659

Lee, J., and Kaletunc, G. (2002). Evaluation of the heat inactivation of Escherichia coli and Lactobacillus plantarum by differential scanning calorimetry. Appl. Environ. Microbiol. 68, 5379-5386. doi: 10.1128/AEM.68.11.5379-5386.2002

Li, H., Garcia-Hernandez, R., Driedger, D., McMullen, L. M., and Gänzle, M. (2016). Effect of the food matrix on pressure resistance of Shiga-toxin producing Escherichia coli. Food Microbiol. 57, 96-102. doi: 10.1016/j.fm.2016.02.002

Lindner, A. B., Madden, R., Demarez, A., Stewart, E. J., and Taddei, F. (2008). Asymmetric segregation of protein aggregates is associated with cellular aging and rejuvenation. Proc. Natl. Acad. Sci. U.S.A. 105, 3076-3081. doi: 10.1073/pnas.0708931105

Line, J. E., Fain, A. R. Jr., Moran, A. B., Martin, L. M., Lechowich, R. V., Carosella, J. M., et al. (1991). Lethality of heat to Escherichia coli O157:H7: D-value and Z-value determinations in ground beef. J. Food Prot. 54, 762-766.

Liu, Y. (2015). Heat and Pressure Resistance of Escherichia coli and Its Inactivation in the Presence of Antimicrobial Compounds. Doctor's thesis, University of Alberta, Edmonton, AB.

Liu, Y., Gill, A., McMullen, L., and Gänzle, M. G. (2015). Variation in heat and pressure resistance of verotoxigenic and non-toxigenic Escherichia coli. J. Food Prot. 78, 111-120. doi: 10.4315/0362-028X.JFP-14-267

Luchansky, J. B., Porto-Fett, A. C. S., Shoyer, B. A., Call, J. E., Schlosser, W., Shaw, W., et al. (2012). Fate of shiga toxin-producing O157:H7 and nonO157:H7 Escherichia coli cells within blade-tenderized beef steaks after cooking on a commercial open-flame gas grill. J. Food Prot. 75, 62-70. doi: 10.4315/0362028X.JFP-11-267

Mackey, B. M., Miles, C. A., Parsons, S. E., and Seymour, D. A. (1991). Thermal denaturation of whole cells and cell components of Escherichia coli examined by differential scanning calorimetry. J. Gen. Microbiol. 137, 2361-2374. doi: 10.1099/00221287-137-10-2361 
Malone, A. S., Chuang, Y. K., and Yousef, A. E. (2006). Genes of Escherichia coli O157:H7 that are involved in high-pressure resistance. Appl. Environ. Microbiol. 72, 2661-2671. doi: 10.1128/AEM.72.4.2661-2671.2006

Mao, Y., Doyle, M. P., and Chen, J. (2001). Insertion mutagenesis of wca reduces acid and heat tolerance of enterohemorrhagic Escherichia coli O157:H7. J. Bacteriol. 183, 3811-3815. doi: 10.1128/JB.183.12.3811-3815.2001

Masuda, N., and Church, G. M. (2002). Escherichia coli gene expression responsive to levels of the response regulator EvgA. J. Bacteriol. 184, 6225-6234. doi: 10.1128/JB.184.22.6225-6234.2002

Mazzotta, A. S. (2001). Thermal inactivation of stationary-phase and acid-adapted Escherichia coli O157:H7, Salmonella, and Listeria monocytogenes in fruit juices. J. Food Prot. 3, 287-429.

Mecsas, J., Rouviere, P. E., Erickson, J. W., Donohue, T. J., and Gross, C. A. (1993). The activity of $\sigma \mathrm{E}$, an Escherichia coli heat-inducible $\sigma$-factor, is modulated by expression of outer membrane proteins. Genes Dev. 7, 2618-2628. doi: 10.1101/gad.7.12b.2618

Mejía, R., Gómez-Eichelmann, M. C., and Fernández, M. S. (1995). Membrane fluidity of Escherichia coli during heat-shock. Biochim. Biophys. Acta 1239, 195-200. doi: 10.1016/0005-2736(95)00152-S

Mercer, R., Zheng, J., Garcia-Hernandez, R., Ruan, L., Gänzle, M., and McMullen, L. (2015). Genetic determinants of heat resistance in Escherichia coli. Front. Microbiol. 6:932. doi: 10.3389/fmicb.2015.00932

Missiakas, D., Betton, J. M., and Raina, S. (1996). New components of protein folding in the extra-cytoplasmic compartments of Escherichia coli: SurA, FkpA and Skp/OmpH. Mol. Microbiol. 21, 871-884. doi: 10.1046/j.13652958.1996.561412.x

Mizunoe, Y., Wai, S. N., Ishikawa, T., Takade, A., and Yoshida, S. (2000). Resuscitation of viable but nonculturable cells of Vibrio parahaemolyticus induced at low temperature under starvation. FEMS Microbiol. Lett. 186, 115-120. doi: 10.1111/j.1574-6968.2000.tb09091.x

Mogk, A., Deuerling, E., Vorderwulbecke, S., Vierling, E., and Bukau, B. (2003). Small heat shock proteins, ClpB and the DnaK system form a functional triade in reversing protein aggregation. Mol. Microbiol. 50, 585-595.

Mogk, A., Tomoyasu, T., Goloubinoff, P., Rüdiger, S., Röder, D., Langen, H., et al. (1999). Identification of thermolabile Escherichia coli proteins: prevention and reversion of aggregation by DnaK and ClpB. EMBO J. 18, 6934-6949. doi: 10.1093/emboj/18.24.6934

Mohácsi-Farkas, C. S., Farkas, J., Mészáros, L., Reichart, O., and Andrássy, É (1999). Thermal denaturation of bacterial cells examined by differential scanning calorimetry. J. Therm. Anal. Calorim. 57, 409-414. doi: 10.1023/A:1010139204401

Morishige, Y., Fujimori, K., and Amano, F. (2013). Differential resuscitative effect of pyruvate and its analogues on VBNC (viable but non-culturable) Salmonella. Microbes Environ. 28, 180-186. doi: 10.1264/jsme2.ME12174

Murphy, R. Y., Marks, B. P., Johnson, E. R., and Johnson, M. G. (1999). Inactivation of Salmonella and Listeria in ground chicken breast meat during thermal processing. J. Food Prot. 9, 975-1096.

Nair, M. S., Lau, P., Belskie, K., Fancher, S., Chen, C., Karumathil, D. P., et al. (2016). Potentiating the heat inactivation of Escherichia coli O157:H7 in ground beef patties by natural antimicrobials. Front. Microbiol. 7:15.

Nakayama, H., Mitsui, T., Nishihara, M., and Kito, M. (1980). Relation between growth temperature of Escherichia coli and phase transition temperatures of its cytoplasmic and outer membranes. Biochim. Biophys. Acta 601, 1-10. doi: 10.1016/0005-2736(80)90508-8

Neetoo, H., and Chen, H. (2011). Individual and combined application of dry heat with high hydrostatic pressure to inactivate Salmonella and Escherichia coli O157:H7 on alfalfa seeds. Food Microbiol. 28, 119-127. doi: 10.1016/j.fm.2011.05.005

Ng, H., Bayne, H. G., and Garibaldi, J. A. (1969). Heat resistance of Salmonella: the uniqueness of Salmonella Senftenberg 775W. Appl. Microbiol. 17, 78-82.

Nicholson, W. L., Munakata, N., Horneck, G., Melosh, H. J., and Setlow, P. (2000). Resistance of Bacillus endospores to extreme terrestrial and extraterrestrial environments. Microbiol. Mol. Biol. Rev. 64, 548-572. doi: 10.1128/MMBR.64.3.548-572.2000

Nishino, K., Inazumi, Y., and Yamaguchi, A. (2003). Global analysis of genes regulated by EvgA of the two-component regulatory system in Escherichia coli. J. Bacteriol. 185, 2667-2672. doi: 10.1128/JB.185.8.2667-2672.2003
Parsell, D. A., and Lindquist, S. (1993). The function of heat-shock proteins in stress tolerance: degradation and reactivation of damaged proteins. Annu. Rev. Genet. 27, 437-496. doi: 10.1146/annurev.ge.27.120193.002253

Pereira, R., Martins, J., Mateus, C., Teixeira, J. A., and Vicente, A. A. (2006). Death kinetics of Escherichia coli in goat milk and Bacillus licheniformis in cloudberry jam treated by ohmic heating. Chem. Pap. 61, 121-126.

Pleitner, A., Zhai, Y., Winter, R., Ruan, L., McMullen, L. M., and Gänzle, M. G. (2012). Compatible solutes contribute to heat resistance and ribosome stability in Escherichia coli AW1.7. Biochim. Biophys. Acta 1824, 1351-1357. doi: 10.1016/j.bbapap.2012.07.007

Podolak, R., Enache, E., Stone, W., Black, D. G., and Elliott, P. H. (2010). Sources and risk factors for contamination, survival, persistence, and heat resistance of Salmonella in low-moisture foods. J. Food Prot. 73, 1919-1936.

Privalle, C. T., and Fridovich, I. (1987). Induction of superoxide dismutase in Escherichia coli by heat shock. Proc. Natl. Acad. Sci. U.S.A. 84, 2723-2726. doi: 10.1073/pnas.84.9.2723

Quinn, P. J. (1981). The fluidity of cell membranes and its regulation. Prog. Biophys. Mol. Biol. 38, 1-104. doi: 10.1016/0079-6107(81)90011-0

Rajic, A., Waddell, L. A., Sargeant, J. M., Read, S., Farber, J., Firth, M. J., et al. (2007). An overview of microbial food safety programs in beef, pork, and poultry from farm to processing in Canada. J. Food Prot. 70, 1286-1294.

Ramos, A., Raven, N. D. H., Sharp, R. J., Bartolucci, S., Rossi, M., Cannio, R., et al. (1997). Stabilization of enzymes against thermal stress and freeze-drying by mannosylglycerate. Appl. Environ. Microbiol. 63, 4020-4025.

Riemann, H. (1968). Effect of water activity on the heat resistance of Salmonella in "dry" materials. Appl. Microbiol. 16, 1621-1622.

Riordan, D. C. R., Duffy, G., Sheridan, J. J., Whiting, R. C., Blair, I. S., and McDowell, D. A. (2000). Effects of acid adaptation, product $\mathrm{pH}$, and heating on survival of Escherichia coli O157:H7 in pepperoni. Appl. Environ. Microbiol. 66, 1726-1729. doi: 10.1128/AEM.66.4.1726-1729.2000

Robey, M., Benito, A., Hutson, R. H., Pascual, C., Park, S. F., and Mackey, B. M. (2001). Variation in resistance to high hydrostatic pressure and rpoS heterogeneity in natural isolates of Escherichia coli O157:H7. Appl. Environ. Microbiol. 67, 4901-4907. doi: 10.1128/AEM.67.10.4901-4907.2001

Ruan, L., Pleitner, A. M., Gänzle, M. G., and McMullen, L. M. (2011). Solute transport proteins and the outer membrane protein $\mathrm{NmpC}$ contribute to heatresistance of Escherichia coli AW1.7. Appl. Environ. Microbiol. 77, 2961-2967. doi: 10.1128/AEM.01930-10

Ryu, J., and Beuchat, L. R. (1998). Influence of acid tolerance responses on survival, growth, and thermal cross-protection of Escherichia coli O157:H7 in acidified media and fruit juices. Int. J. Food Microbiol. 45, 185-193. doi: 10.1016/S0168-1605(98)00165-2

Ryu, J., and Beuchat, L. R. (1999). Changes in heat tolerance of Escherichia coli O157:H7 after exposure to acidic environments. Food Microbiol. 16, 317-324. doi: 10.1006/fmic. 1998.0234

Santillana Farakos, S. M., Schaffner, D. W., and Frank, J. F. (2014). Predicting survival of Salmonella in low-water activity foods: an analysis of literature data. J. Food Prot. 77, 1448-1461. doi: 10.4315/0362-028X.JFP-14-013

Sharma, M., Adler, B. B., Harrison, M. D., and Beuchat, L. R. (2005). Thermal tolerance of acid-adapted and unadapted Salmonella, Escherichia coli O157:H7, and Listeria monocytogenes in cantaloupe juice and watermelon juice. Lett. Appl. Microbiol. 41, 448-453. doi: 10.1111/j.1472-765X.2005.01797.x

Sinensky, M. (1974). Homeoviscous adaptation: a homeostatic process that regulates the viscosity of membrane lipids in Escherichia coli. Proc. Natl. Acad. Sci. U.S.A. 71, 522-525. doi: 10.1073/pnas.71.2.522

Smith, S. E., Maurer, J. L., Orta-Ramirez, A., Ryser, E. T., and Smith, D. M. (2001) Thermal inactivation of Salmonella spp., Salmonella typhimurium DT104 and Escherichia coli O157:H7 in ground beef. J. Food Sci. 66, 1164-1168. doi: 10.1111/j.1365-2621.2001.tb16099.x

Studer, P., Heller, W. E., Hummerjohann, J., and Drissner, D. (2013). Evaluation of aerated steam treatment of alfalfa and mung bean seeds to eliminate high levels of Escherichia coli O157:H7 and O178:H12, Salmonella enterica, and Listeria monocytogenes. Appl. Environ. Microbiol. 79, 4613-4619. doi: 10.1128/AEM.00443-13

Suutari, M., and Laakso, S. (1994). Microbial fatty acids and thermal adaptation. Crit. Rev. Microbiol. 20, 285-328. doi: 10.3109/104084194091 13560 
Swartz, R. S., Luchansky, J. B., Kulas, M., Shoyer, B. A., Shane, L. E., Strasser, H., et al. (2015). Thermal inactivation of shiga toxin-producing Escherichia coli cells within cubed beef steaks following cooking on a griddle. J. Food Prot. 78, 1013-1017. doi: 10.4315/0362-028X.JFP-14-454

Syamaladevi, R. M., Tang, J., Villa-Rojas, R., Sablani, S., Carter, B., and Campbell, G. (2016). Influence of water activity on thermal resistance of microorganisms in low-moisture foods: a review. Compr. Rev. Food Sci. Food Saf. 15, 353-370. doi: $10.1111 / 1541-4337.12190$

Thomas, J. G., and Baneyx, F. (1998). Roles of the Escherichia coli small heat shock proteins IbpA and IbpB in thermal stress management: comparison with ClpA, ClpB, and HtpG in vivo. J. Bacteriol. 180, 5165-5172.

Torok, Z., Horvath, I., Goloubinoff, P., Kovacs, E., Glatz, A., Balogh, G., et al. (1997). Evidence for a lipochaperonin: association of active proteinfolding GroESL oligomers with lipids can stabilize membranes under heat shock conditions. Proc. Natl. Acad. Sci. U.S.A. 94, 2192-2197. doi: 10.1073/pnas.94.6.2192

Tsuchido, T., Katsui, N., Takeuchi, A., Takano, M., and Shibasaki, I. (1985). Destruction of the outer membrane permeability barrier of Escherichia coli by heat treatment. Appl. Environ. Microbiol. 50, 298-303.

Vaara, M. (1992). Agents that increase the permeability of the outer-membrane. Microbiol. Rev. 56, 395-411.

Vasan, A., Geier, R., Ingham, S. C., and Ingham, B. H. (2014). Thermal tolerance of O157 and non-O157 shiga toxigenic strains of Escherichia coli, Salmonella, and potential pathogen surrogates, in frankfurter batter and ground beef of varying fat levels. J. Food Prot. 77, 1501-1511. doi: 10.4315/0362-028X.JFP14-106

Veinger, L., Diamant, S., Buchner, J., and Goloubinoff, P. (1998). The small heatshock proteins IbpB from Escherichia coli stabilizes stress-denatured proteins for subsequent refolding by a multichaperone network. J. Biol. Chem. 273, 11032-11037. doi: 10.1074/jbc.273.18.11032

Weiss, A., and Hammes, W. P. (2005). Efficacy of heat treatment in the reduction of Salmonella and Escherichia coli $\mathrm{O} 157: \mathrm{H}$ - on alfalfa, mung bean, and radish seeds used for sprout production. Eur. Food Res. Technol. 221, 187-191. doi: 10.1007/s00217-004-1125-9

Whitfield, C., and Valvano, M. A. (1993). Biosynthesis and expression of cellsurface polysaccharides in gram-negative bacteria. Adv. Microb. Physiol. 35, 135-246. doi: 10.1016/S0065-2911(08)60099-5

Winkler, J., Seybert, A., Konig, L., Pruggnaller, S., Haselmann, U., Sourjik, V., et al. (2010). Quantitative and spatio-temporal features of protein aggregation in
Escherichia coli and consequences on protein quality control and cellular ageing. EMBO J. 29, 910-923. doi: 10.1038/emboj.2009.412

Woodward, D. L., Clark, C. G., Caldeira, R. A., Ahmed, R., and Rodgers, F. G. (2002). Verotoxigenic Escherichia coli (VTEC): a major public health threat in Canada. Can. J. Infect. Dis. 13, 321-330. doi: 10.1155/2002/383840

Yang, J., Bingol, G., Pan, Z., Brandl, M. T., McHugh, T. H., and Wang, H. (2010). Infrared heating for dry-roasting and pasteurization of almonds. J. Food Eng. 101, 273-280. doi: 10.1016/j.jfoodeng.2010.07.007

Yeni, F., Yavasć, S., Alpas, H., and Soyer, Y. (2015). Most common foodborne pathogens and mycotoxins on fresh produce: a review of recent outbreaks. Crit. Rev. Food Sci. Nutr. 56, 1532-1544. doi: 10.1080/10408398.2013.777021

Yoon, Y., Lee, H., Lee, S., Kim, S., and Choi, K. H. (2015). Membrane fluidity-related adaptive response mechanisms of foodborne bacterial pathogens under environmental stresses. Food Res. Int. 72, 25-36. doi: 10.1016/j.foodres.2015.03.016

Yuk, H., and Marshall, D. L. (2003). Heat adaptation alters Escherichia coli O157:H7 membrane lipid composition and verotoxin production. Appl. Environ. Microbiol. 69, 5115-5119. doi: 10.1128/AEM.69.9.5115-5119.2003

Zhang, Y., and Griffiths, M. W. (2003). Induced expression of the heat shock protein genes uspA and grpE during starvation at low temperatures and their influence on thermal resistance of Escherichia coli O157:H7. J. Food Prot. 66, 2045-2050.

Zhang, Y., and Rock, C. O. (2008). Membrane lipid homeostasis in bacteria. Nat. Rev. Microbiol. 6, 222-233. doi: 10.1038/nrmicro1839

Zhao, G., Ceci, P., Ilari, A., Giangiacomo, L., Laue, T. M., Chiancone, E., et al. (2002). Iron and hydrogen peroxide detoxification properties of DNA-binding protein from starved cells. A ferritin-like DNA-binding protein of Escherichia coli. J. Biol. Chem. 277, 27689-22796. doi: 10.1074/jbc.M202094200

Conflict of Interest Statement: The authors declare that the research was conducted in the absence of any commercial or financial relationships that could be construed as a potential conflict of interest.

Copyright $\odot 2016$ Li and Gänzle. This is an open-access article distributed under the terms of the Creative Commons Attribution License (CC BY). The use, distribution or reproduction in other forums is permitted, provided the original author(s) or licensor are credited and that the original publication in this journal is cited, in accordance with accepted academic practice. No use, distribution or reproduction is permitted which does not comply with these terms. 